\title{
Epistolary Heritage by A. Y. Krymsky: Pre- Revolutionary Correspondence of A. Y. Krymsky and V.V. Bartold (1908-1913)
}

\author{
R.M. Valeev, R.Z. Valeeva, D. R. Khayrutdinov, S. A. Kirillina
}

\begin{abstract}
The article presents the material about the unpublished correspondence of Ahatanhel Yukhymovych Krymsky and Vasily Vladimirovich Bartold in 1908-1913 containing historical and scientific information that allows us to expand our ideas about the directions and problems of Russian oriental studies at the beginning of the 20th century. The correspondence of two outstanding scholars from Russia and Ukraine testifies to the fact that they were brought together by the human community and the similarity of professional interests. The letters of V.V. Bartold and A.E. Krymsky show how much they were concerned about the state of science about the East and its teaching system.
\end{abstract}

Keywords: Russia, Ukraine, East, orientalism, epistolary heritage, the Islamic world.

\section{INTRODUCTION:}

In the research focus of modern scholars, there are theoretical, geopolitical, sociocultural and historical and scientific factors that conditioned the formation and development of key Russian centers for practical, academic and university oriental studies in Moscow, St. Petersburg, Kazan, Kiev, and Vladivostok, Tashkent in the 19th - the first decades of the 20th century. Russian oriental studies at the turn of the 19th-20th centuries was distinguished by the institutional diversity, original scientific heritage, and versatility of research areas of the study of the East. In the study of the phenomenon of oriental studies in Russia and the Soviet Union, special attention is paid to the epistolary heritage of Russian orientalists. Currently, search, study, systematization, and publication of the correspondence of the prominent Arabist, Semitologist, Turkologist, Iranian scholar, and Slavist A. Y. Krymsky with prominent Orientalists V.R. Rosen, V.V. Bartold, P.K. Kokovtsov, F.E.Korsch, V.A. Zhukovsky, S.F. Oldenburg, I.Yu. Krachkovsky, N.A. Mednikov, V.F. Minorsky and other scientists in the period of the 1890s - 1930s are being conducted.

\section{Proposed Methodology}

Our systematic methodology of dealing with "documents of personal origin", namely the correspondence of prominent Russian orientalists, is represented by a combination of four key research methods. Firstly, the search, processing and expansion of the archival-epistolary base on the basis of a systematic (complete) study of the personal funds of orientalists in the archives of Russia and Ukraine (with possibly some other countries as well). In addition to

Revised Manuscript Received on November 08, 2019.

R.M. Valeev: Kazan (Volga region) Federal University 18, Kremlevskaya Str., Kazan, 420008

R.Z. Valeeva: Kazan Innovative University named after V.G. Timiryasov (IEML) 42 Moskovskaya Str., Kazan, 420111

D. R. Khayrutdinov: Kazan Innovative University named after V.G. Timiryasov (IEML) 42 Moskovskaya Str., Kazan, 420111

S. A. Kirillina: Lomonosov Moscow State University1 Ленинские горы, Москва, 119991 correspondence, the methodology includes the involvement of various materials (official documents, plans, notebooks, etc.). Secondly, the search and systematization of bilateral correspondence (Krymsky - Rosen, Krymsky - Bartold, Krymsky - Minorsky, etc.). Thirdly, the historiographic, source study-related and thematic search for and synthesis of historical and scientific facts and information presented in the correspondence, as well as the subsequent categorization and commentary in order to come to certain conclusions about the phenomenon of the relations between the aforementioned academics and to establish the picture of scholarly life in the Russian Empire in the late $19^{\text {th }}$ and early $20^{\text {th }}$ centuries.

\section{Results Analysis}

The history of Russian oriental studies, directions, patterns, and results of the development of oriental studies, the scientific, educational and especially epistolary heritage of Russian orientalists are topical academic and applied problems of modern Russian and foreign historiography and source study of oriental studies. At the present stage, theoretical, geopolitical, sociocultural and historicalscientific directions and factors of the formation and development of key centers of the academic, university and practical oriental studies in the historical retrospective are causing increased attention of scientists and the public.

The legacy of such luminaries of Russian oriental studies as A.K. Kazembek (1802-1870), F.E. Korsch (1843-1915), V.R. Rosen (1849-1908), V.D. Smirnov (1855-1918), N.A. Mednikov (1855-1918), V.A. Zhukovsky (1858-1918), S.F. Oldenburg (1863-1934), V.V. Bartold (1869-1930), A. Y. Krymsky (1871-1942), I.Yu. Krachkovsky (1883-1951), P.K. Kokovtsov (18611942), A.E. Snesarev (1865-1937), V.F. Minorsky (18771966) and others are of particular scientific and educational interest. Their destinies and heritage are closely intertwined, as evidenced by their unpublished epistolary heritage, preserved in the archival centers of St. Petersburg, Moscow and Kiev.In an era when the epistolary genre is almost extinct, it is extremely interesting to look at the yellowed archive sheets that convey to us the thoughts, feelings, and experiences of prominent Russian orientalists. Undoubtedly, such are the well-known domestic Orientalists Vasily Vladimirovich Bartold and Ahatanhel Yukhymovych Krymsky. They were people of the same generation but grew up in various socio-political and social conditions. Both received an excellent education and eventually became prominent representatives of three oriental schools in Russia - St. Petersburg, Moscow and Kiev. Both were broad spectrum orientalists, specialists in philology, history, culture, and ethnography of the Arab-Muslim East. Both 


\section{Epistolary Heritage by A. Y. Krymsky: Pre-Revolutionary Correspondence of A. Y. Krymsky and V.V. Bartold (1908-1913)}

were elected Academicians - V.V. Bartold in 1913 to the Russian Academy of Sciences (RAS) and A. Y. Krymsky in 1918 to the Ukrainian Academy of Sciences (UAN). Over the years, A. Y. Krymsky and V.V. Bartold corresponded, since A. Y. Krymsky lived in Moscow and taught at the Lazarev Institute of Oriental Languages, and V.V. Bartold since 1901 was a professor at the Faculty of Oriental Languages at St. Petersburg University. It reflected their personal perception of what is happening in professional and public life so we can understand the hidden motives of many political and cultural processes of that time. Therefore, their unpublished and non-scientific correspondence is an important source of information on the history of Russian oriental studies. The funds of the Institute of Manuscripts of V.I. Vernadsky National Library of Ukraine 9 letters of V.V. Bartold addressed to A. Y. Krymsky are preserved, while the funds of the St. Petersburg Branch of the Archive of the Russian Academy of Sciences contains 7 reciprocal letters from A. Y. Krymsky. On the whole, the correspondence that has survived to our times covers a twenty-year period, from 1908 to 1928 . These years were crucial and dramatic in the history of Russia, the Russian academic and university oriental studies. This publication focuses on the block of this epistolary, which contains letters from the pre-revolutionary period (1908-1913), when A. Y. Krymsky lived and worked in Moscow, and V. V. Bartold in St. Petersburg.In the periods of their life in Moscow, St. Petersburg and Kiev in the pre-revolutionary and Soviet periods, A. Y. Krymsky and V.V. Bartold never met.The first letter belonging to V.V. Bartold is dated December 12, 1908. It has a purely business-like character and is clearly written under the impression after reading a copy of the new edition of the work of A. Y. Krymsky "History of Persia, its Literature and Dervish Theosophy"1. The famous Petersburg historian and source historian immediately noticed some inaccuracies, which he hastened to point out to his colleague. "There are no London manuscripts of Gardizi; 2- V.V. Bartold wrote, one is located in Oxford, the other in Cambridge. ... The amendment will probably have to stipulate some inconsistency in the author's naming of Gardizi: on pp. 3-4 Karuiziy ..., from p. 43 the form of "Gardizy" is preferred without explanation of the reason; on p. 47 you, contrary to your custom, do not decline this name and write Gardizi. Compare also Nesr (in the table of contents) and Nasr (in the text), etc."3.The response of A. Y. Krymsky to this first letter did not preserve. In the next letter by V.V. Bartold, dated February 11, 1909, the discussion on the book "History of Persia, its Literature and Dervish Theosophy" continued, and the author of the letter pointed out to his colleague the nuances that, in his opinion, were subject to correction: "I must admit that I don't like... your presentation (this is, of course, a matter of taste). Expressions such as "tiny details" (p. 6 note 4) ... etc. make a strange impression within the university course "; V.V. Bartold notes omissions

${ }^{1}$ First edition: Krymsky A. Y. Istoriya Persii, ee literatury i dervisheskoi teosofii (History of Persia, Its Literature and Dervish Theosophy). Vol. 1. Issue I. Moscow, 1901

${ }^{2}$ Gardizi, Abu Said - XI century Persian historian.

${ }^{3}$ Institut rukopisi Natsional'noi biblioteki Ukrainy imeni V.I. Vernadskogo (IR NBUV), fond 1, delo 22664. L.1-1 ob. Institute of Manuscripts of V.I Vernadsky National Library of Ukraine, f.I, No. 22664. L. $11 \mathrm{ob.}$

in the work: "Among the books, if I am not mistaken, you do not at all mention ... the books Le Strange, The lands of the Califate4, as well as the most part of other English geographical writings." At the same time, the letter also touched upon the more general problems of modern oriental science in Russia. In particular, V.V. Bartold wrote: "As for your books, I explain many of their shortcomings, besides the conditions in which you had to work, and other reasons, by the state of our science. I fully admit that in this respect there is a kind of circulus vitiosus (vicious circle - Auth.): for any clear idea [of] the details, especially for students, general courses of political history are necessary, meanwhile, until the details haven't been studied, it is impossible to have a clear idea of the whole and the introduction of a causal connection of events ... You write that, due to the reasons you set out, your works "will appear only in a minimally tolerable form" and not in the way you would like to see them. It seems to me that not only you, but no one else is able to write now, in two or three years (your books, if I am not mistaken, are written much faster), a somewhat tolerable book entitled "History of Persia, its Literature and Dervish Theosophy". It requires the labor of a lifetime, yet we can't even dream about the higher levels of perfection"5. At the same time, the general tone of the letter is very benevolent. It can be seen that V.V. Bartold was guided by the desire to help a colleague to improve his work, and not to emphasize his shortcomings. V.V. Bartold who was the secretary of the Eastern branch of the Imperial Russian Archaeological Society, and after the death of V.R. Rosen6in 1908 also headed the editorial board of his "Notes", assured A. Y. Krymsky that will continue to regularly send him copies of this publication, as was introduced earlier. We emphasize that on the front side of the envelope by the hand of A. Y. Krymsky it is written in pencil in Ukrainian "amendments to the "History of Persia" which indicates the importance of V.V. Bartold's comments for him.At the very end of the letter, there is a rather remarkable note by V.V. Bartold: "It goes without saying that I will be at the service of Mr. Freytag whenever he finds it necessary to contact me for help, advice, etc." Since the name of this person is not mentioned in the first letter of V.V. Bartold, it can be assumed that the unpreserved answer of A. Y. Krymsky contained some information about him. Indeed, the situation is clarified when reading the contents of the letter by A. Y. Krymsky from March 1, 1909, which he wrote to V.V. Bartold after a debilitating illness. It says that Konstantin Andreevich Freytag (1874-1934) was a student of A. Y. Krymsky and F.E. Korsh7at the Lazarev Institute of Oriental Languages in Moscow and was preparing to take the master's exam at the Faculty of

\footnotetext{
${ }^{4}$ Le Strange, Guy. The Lands of the Eastern Caliphate: Mesopotamia, Persia and Central Asia from the Moslem Conquest to the Time of Timur. Cambridge, 1905

5 (IR NBUV), fond 1, delo 22664. L.1-1 ob.

6Victor Romanovich Rozen (1849-1908) - Orientalist Arabist, Academician of the Imperial Academy of Sciences, from 1885 headed the Eastern Branch of the Imperial Russian Archaeological Society.

7Korsh Fedor Evgenievich (1843-1915) is a classic, Slavist, Iranianist. From 1892 he taught Persian at the Lazarev Institute of Oriental Languages and in 1900 was elected an Ordinary Academician of the Russian Language and Literature Department of the Imperial Academy of Sciences.
} 
Oriental Studies at St. Petersburg University.Quite complete information about him is contained in the later correspondence of A. Y. Krymsky with I.Yu. Krachkovsky, who in 1936 told his colleague about the death of K.A. Freytag. In his reply dated October 10 of the same year, A.E. Krymsky wrote that Konstantin Freytag was actually his first student.In 1893, while still a student of Ahatanhel Krymsky, in the estate near Moscow, Shultsev-Freytag prepared Kostya Freytag for an examination for the certificate of maturity in Latin and Ancient Greek. According to the testimony of A. Y. Krymsky, his student, who was only three years younger than him, was already fluent in several European languages at that time, since he traveled a lot with his family, and classical languages were not a problem for him. Young people became friends and continued to communicate a lot8. They lost contact for several years after A. Y. Krymsky went to Beirut in 1896. In 1903, K.A. Freytag decided to enter the Lazarev Institute of Oriental Languages. However, in 1906 K.A. Freytag got a job in a bank in Tehran and, having interrupted his studies, went to Iran9. Having returned to Russia in 1908, he immediately turned to A. Y. Krymsky with a request to help him again to prepare for the exam at St. Petersburg University. It was at this time that A. Y. Krymsky turned for assistance to V.V. Bartold, giving Konstantin Freytag very flattering characteristic. In a reply letter, V.V. Bartold, who was well familiar with university affairs, expressed his willingness to provide K.A. Freytag any assistance, but he remarked: "I couldn't say anything about what demands on the history of the East would be made to him, since I don't take any part in the commission; a member of the commission on the history of the East is N.I. Veselovsky 10. I'm pretty sure that Mr. Freytag will pass all the exams in the spring without any difficulty."11.Konstantin Freytag, who forgot a lot over these two years, nevertheless presented to Professor N.A. Mednikov12his own translation of "The Life of the Prophet", in which A. Y. Krymsky immediately recognized the text prepared earlier by his own student V. F. Minorsky13with his numerous edits made

\footnotetext{
${ }^{8}$ A wealthy Freytag financed for some time the publication of the journals "Zhytie u slovo" and "Narod," and in 1896 the Ukrainian translation of William Clouston's book "Popular Tales and Fictions, their Migrations and Transformations." (Clouston W.A. Popular Tales and Fictions, their Migrations and Transformations. London, 1887; translation: Klouston W.A. Narodni kazky ta vygadky, jikh vandrivky ta pereminy. Z anglijs'koji movy perelozhyv A. Krymsky. Lviv, 1896). However, the inheritance received by Konstantin Freytag from his father radically changed his life, not for the better: he preferred not to study at the university but to play cards and other entertainment, which worried Agafangel Efimovich very much.

9 "Perepiska akademikov A. Y. Krymskogo i I.Y. Krachkovskogo 1920 1930-kh godov. (Publikatsiya I.M. Smilyanskoi) // Neizvestnye stranitsy otechestvennogo vostokovedeniya ("Correspondence of the Academicians A. Y. Krymsky and I.J. Krachkovsky in the 1920-1930s. (Publication of I.M. Smilyanskaya)". Unknown Pages of the Russian Oriental Studies). Moscow, 1997. Pp. 240-244.

${ }^{10}$ Veselovsky Nikolai Ivanovich (1848-1918) - Archeologist, Orientalist, researcher of history and archeology of Central Asia, since 1890 - Professor of St. Petersburg University.

${ }^{11}$ IR NBUV, fond XXXVI, No. 194. L. 1.

${ }^{12}$ Mednikov Nikolai Alexandrovich (1855-1918) - Arabist, since 1903 Professor of St. Petersburg University.

${ }^{13}$ Minorsky Vladimir Fedorovich (1877-1966) - Orientalist, diplomat, researcher of history, historical geography, literature, and culture of Persia and Transcaucasia.
}

during classes with Konstantin Freytag. A.E. Krymsky could not remain silent, considering this as plagiarism, and discussed this issue in writing with N.A. Mednikov, who wrote to him in reply: "I hope that your Council will not leave this outrageous case without consequences and will repel expropriation, which is already part of the customs of our time"14. A commission was created under the professorial council of the Lazarev Institute, which for a long time could not decide whether to consider the submitted translation as plagiarism. However, A. Y. Krymsky and K.A. Freytag stopped communicating forever.In their letters, A. Y. Krymsky and V.V. Bartold continued to discuss research and educational issues. In particular, A. Y. Krymsky wrote: "How grateful I am for the "Turkestan"! Thank you very, very much for it. But at the same time, I would like to take care of my students, who often would like to purchase this book and do not know its price. At what price could they be sent to our students?"15V.V. Bartold responded as follows: "About Turkestan, unfortunately, I must answer you that there are no more copies of this book on sale and it cannot be ordered from anywhere. Even I personally now have only 5 copies left. In this regard, we note that the first part of the book by V. V. Bartold "Turkestan in the Era of the Mongol Invasion" published in 1898, ${ }^{16}$ was extremely popular among Russian and European orientalists. V.V. Bartold began working on it in 1895 when he received the opportunity to make extracts from Eastern manuscripts in the libraries of London, Oxford, Paris, and Leiden. This work, which has become a classic, contains an overview of Persian and Arabic sources on the history of Central Asia in the VII-XI centuries. It also contains a multilateral analysis of the facts that determined the development of history before the Mongols came to Turkestan and the course of its conquest.V.V. Bartold painstakingly worked on oriental texts, making extracts from historical writings, and although many of them are represented in the work "Turkestan in the Era of the Mongol Invasion" in small fragments, their value is undoubted. That is why A. Y. Krymsky spoke highly of this publication and often turned to it in his work, as evidenced by one of the remarks in his letters to V.V. Bartold: "In the first issue of the" History of Persia", the chapter on Tahirids, Samanids, etc., was compiled ... in very close dependence on your "Turkestan""17. In a brief letter dated October 12, 1913, A. Y. Krymsky sincerely congratulated V.V. Bartold on his election as a Member of the Imperial Academy of Sciences, but he did not forget about the business, writing: "I take this opportunity to remind you that you used to have a very pleasant habit for me - to send impressions of all works. Lately, I have not received anything from you, and, for

\footnotetext{
${ }^{14}$ IR NBUV, fond XXXVI, No. 366. L. 2.

15 Sankt-Peterburgskii filial Arkhiva Rossiiskoi akademii nauk (SPb ARAN), fond 68, op. 2, d. 128. L.1. (St. Petersburg Branch of the Archive of the Russian Academy of Sciences, f. 68, inventory 2, № 128. L.1.

${ }^{16}$ Bartold V.V. Turkestan $\mathrm{v}$ epokhu mongol'skogo nashestviya. Ch. 1. Teksty (Turkestan in the Era of the Mongol Invasion. Part 1. Texts). St Petersburg, 1898. Ch. 2. Issledovanie (Part 2. Research). St. Petersburg, 1900.

${ }^{16} \mathrm{SPb}$ ARAN, fond 68, inventory 2, No. 128. L. $1 \mathrm{ob}$
} 


\section{Epistolary Heritage by A. Y. Krymsky: Pre-Revolutionary Correspondence of A. Y. Krymsky and V.V. Bartold (1908-1913)}

example, I do not have an impression of Harun's relationship with Karl, as well as works on Ani. I would be grateful if you again place me in the list of those to whom you send imprints and works." ${ }^{18}$.To a certain extent, the election of V.V. Bartold as an Academician contributed to his works on the role of Islam in the medieval times in the Arab-Muslim East. He published the first Islamic study article in 1894. However, it was his work "Theocratic Idea and Secular Power in a Muslim State" that brought him popularity as a specialist on Islam. ${ }^{19}$. According to A.B. Khalidov $^{20}$, who was preparing a scholar's works on the history of Islam and the Arab Caliphate, originally it was a speech delivered by him when he entered a professorship in Petersburg University ${ }^{21}$. It was then printed twice as an article, which, according to its author, was "a brief overview of the history of state life and the attitude of secular authorities to religion in the Muslim East", which "will be enough to refute the current view of stagnation as a characteristic feature of the East, and about theocracy, as the only form of government possible in Muslim countries"22. The further development of Islamic studies, first touched upon in the "Turkestan", resulted in the work "Caliph and Sultan". ${ }^{23}$ - one of the most vivid and reasoned studies of V.V. Bartold and in his other studies.

Another vector of scientific interests of V.V. Bartold found expression in his work "Charlemagne and Harun al-Rashid"24, published in 1912 in the first volume of the journal "Christian East". In it V.V. Bartold appreciated the long-standing dispute between medievalists and orientalists about the existence of diplomatic relations between the Frankish Kingdom and the Baghdad Caliphate during the time of Charlemagne (768-814) and Harun alRashid (786-809) and a little earlier in the times of Pippinus Brevis (751-768) and al-Mansur (754-775). He came in this issue to a negative conclusion, based on the knowledge of the political history of the time, as well as on numerous sources, including the Arab and Frankish chronicles, and evidence of material culture. This heated debate in the academic environment has intensified even more in subsequent years. Later V.V. Bartold wrote in a detailed article "On the Question of French-Muslim Relations" (1915) that "compared to the medieval East, Muslim and Christian, Western Europe of that time was just as backward as the East now compared to Western Europe" 25.

${ }^{18} \mathrm{SPb}$ ARAN, fond 68, inventory 2, No. 128. L. 2.

\footnotetext{
${ }^{19}$ Bartold V.V. "Teokraticheskaya ideya i svetskaya vlast' v musul'manskom gosudarstve". Bartold V.V. Sochineniya. T. VI. Raboty po istorii islama i Arabskogo khalifata ("The Theocratic Idea and Secular Power in the Muslim State". Bartold V.V. Works. Vol. VI. Works on the History of Islam and the Arab Caliphate). Moscow, 1966. Pp. 303-319.

${ }^{20}$ Khalidov Anas Bakievich (1929-2001) is a prominent Russian Arabist.

${ }^{21}$ Khalidov A.B. "Predislovie" //Bartold V.V. Sochineniya. (Khalidov A.B "Preface" / Bartold V.V. Works). Vol. VI. P.7.

${ }^{22}$ Quote: Khalidov A.B. "Predislovie" (Khalidov A.B "Preface") P.7.

${ }^{23}$ Бартольд В.В. Халиф и султан // Бартольд В.В. Сочинения. Т. VI. С. 7.Bartold V.V. "Khalif i sultan" // Bartold V.V. Sochineniya. ("The Caliph and the Sultan". Bartold V.V. Works. Vol. VI. P.7

${ }^{24}$ Bartold V.V. "Karl Velikii i Kharun ar-Rashid" // Bartold V.V. Sochineniya. ("Charlemagne and Harun al-Rashid". Bartold V.V. Works. Vol. VI. Pp. 342-364.

${ }^{25}$ Bartold V.V. "K voprosu o franko-musul'manskikh otnosheniyakh" //Bartold V.V. Sochineniya. ("On the Issue of Franco-Muslim Relations". Bartold V.V. Works. Vol. VI. P.461.
}

\section{CONCLUSION}

The correspondence of these well-known orientalist scholars, not yet introduced into scientific circulation, is the object of research within the framework of a scientific project whose goal is to study, systematize and prepare for publication the unknown epistolary heritage of Orientalists in Russia, Ukraine and Europe who worked at the turn of the 19th-20th centuries, and specifically research work with the correspondence of A. Y. Krymsky with V.R. Rosen, F.E. Korsh, V.A. Zhukovsky, S.F. Oldenburg, V.V. Bartold, N.A. Mednikov, P.K. Kokovtsov, V.F. Minorsky, and others.In general, the scientific, social and cultural component of the epistolary heritage of A. Y. Krymsky and Russian orientalists are of undoubted interest to contemporaries for the following reasons. His letters and the response letters of scientists are autographs of the largest Russian orientalists of the late nineteenth century beginning of the twentieth century. This correspondence contains materials that give an idea of their scientific and social position and allows us to estimate the scale of their personalities. And finally, we find in them unique assessments of that difficult time, as well as the state of Russian and European oriental studies in general, and Arabic, Ottoman, Iranian, and Turkic studies in particular.

\section{REFERENCES}

1. Institut rukopisi Natsional'noi biblioteki Ukrainy imeni V.I Vernadskogo (IR NBUV), fond I, dela 22664-22671 [Pis'ma V.V. Bartol'da - A. Y. Krymskomu] (Institute of Manuscripts of V.I Vernadsky National Library of Ukraine, f. I, № 22664-22671 [Letters of V.V. Bartold to A. Y. Krymsky]).

2. Institut rukopisi Natsional'noi biblioteki Ukrainy imeni V.I. Vernadskogo (IR NBUV), fond XXXVI, delo 194 [Pis'ma V.V Bartol'da - A. Y. Krymskomu] (Institute of Manuscripts of V.I. Vernadsky National Library of Ukraine, f. XXXVI, № 194 [Letter of V.V. Bartold to A.E. Krymsky]).

3. Institut rukopisi Natsional'noi biblioteki Ukrainy imeni V.I. Vernadskogo (IR NBUV), fond XXXVI, delo 366 [Pis'ma V.V Bartol'da - A. Y. Krymskomu] (Institute of Manuscripts of V.I. Vernadsky National Library of Ukraine, f. XXXVI, № 366 [Letter of N.A. Mednikov to A. Y. Krymsky]).

4. Sankt-Peterburgskii filial Arkhiva Rossiiskoi akademii nauk ( $\mathrm{SPb}$ ARAN), fond 68, op. 2, d. 128 [Pis'ma A. Y. Krymskogo - V.V. Bartol'du] (St. Petersburg Branch of the Archive of the Russian Academy of Sciences, f. 68, inventory 2, № 128 [Letters to A. Y. Krymsky to V.V. Bartold]).

5. Bartold V.V. "Ani". Bartold V.V. Sochineniya. T. III. Raboty po istoricheskoi geografii ("Ani”. Bartold V.V. Works. Vol. III. Works on Historical Geography). Moscow, 1965. Pp. 327-330.

6. Bartold V.V. "Karl Velikii i Kharun ar-Rashid". Bartold V.V. Sochineniya. T. VI. Raboty po istorii islama i Arabskogo khalifata ("Charlemagne and Harun al-Rashid". Bartold V.V. Works. Vol. VI. Works on the History of Islam and the Arab Caliphate). Moscow, 1966. Pp. 342-364

7. Bartold V.V. "Khalif i sultan". Bartold V.V. Sochineniya. T. VI Raboty po istorii islama i Arabskogo khalifata ("The Caliph and the Sultan". Bartold V.V. Works. Vol. VI. Works on the History of Islam and the Arab Caliphate). Moscow, 1966. Pp. 15-80.

8. Bartold V.V. "K voprosu o franko-musul'manskikh otnosheniyakh". Bartold V.V. Sochineniya. T. VI. Raboty po istorii islama Arabskogo khalifata ("On the Issue of Franco-Muslim Relations". Bartold V.V. Works. Vol. VI. Works on the History of Islam and the Arab Caliphate). Moscow, 1966. Pp. 432-461.

9. Bartold V.V. "Otzyv o trudakh N.Y. Marra po issledovaniyu drevnostei Ani”. Bartold V.V. Sochineniya. T. IV. Raboty po arkheologii, numizmatike, epigrafike i etnografii 
("Review of Works of N.Y. Marr on the Study of the Antiquities of Ani". Bartold V.V. Works. Vol. IV. Works on Archeology, Numismatics, Epigraphy and Ethnography). Moscow, 1966. Pp. 202235 .

10. Bartold V.V. "Persidskaya nadpis' na stene Aniiskoi mecheti Manuche". Bartold V.V. Sochineniya. T. IV. Raboty po arkheologii, numizmatike, epigrafike i etnografii ("A Persian Inscription on the Wall of the Mosque Manuche Ani". Bartold V.V. Works. Vol. IV. Works on Archeology, Numismatics, Epigraphy and Ethnography). Moscow, 1966. Pp. 313-338.

11. Bartold V.V. "Teokraticheskaya ideya i svetskaya vlast' v musul'manskom gosudarstve". Bartold V.V. Sochineniya. T. VI. Raboty po istorii islama i Arabskogo khalifata ("The Theocratic Idea and Secular Power in the Muslim State". Bartold V.V. Works. Vol. VI. Works on the History of Islam and the Arab Caliphate). Moscow, 1966. Pp. 303-319.

12. Bartold V.V.Turkestan v epokhu mongol'skogo nashestviya. Ch. 1. Teksty(Turkestan in the Era of the Mongol Invasion. Part 1. Texts) St. Petersburg, 1898.Ch. 2.Issledovanie (Part 2. Research). St. Petersburg, 1900

13. Clouston W.A. Narodni kazky ta vygadky, ikh vandrivky ta pereminy (Popular Tales and Fictions, their Migrations and Transformations). Transl. from English by A. Y. Krymsky. Lvov, 1896.

14. Khalidov A.B. "Predislovie". Bartold V.V. Sochineniya. T. VI Raboty po istorii islama i Arabskogo khalifata ("Preface". Bartold V.V. Works. Vol. VI. Works on the History of Islam and the Arab Caliphate). Moscow, 1966. Pp. 5-13.

15. Krymsky A. Y. Istoriya Persii, ee literatury i dervisheskoi teosofii (History of Persia, Its Literature and Dervish Theosophy). Vol. 1. Issue I. Moscow, 1901.

16. "Perepiska akademikov A. Y. Krymskogo i I.Y. Krachkovskogo 1920-1930-kh godov. (Publikatsiya I.M. Smilyanskoi) “. Neizvestnye stranitsy otechestvennogo vostokovedeniya ("Correspondence of the Academicians A. Y. Krymsky and I.J. Krachkovsky in the 1920 1930s. (Publication of I.M. Smilyanskaya)". Unknown Pages of the Russian Oriental Studies). Moscow, 1997. Pp. 155-368.

17. Clouston W.A. Popular Tales and Fictions, their Migrations and Transformations. London, 1887.

18. Le Strange, Guy.The Lands of the Eastern Caliphate: Mesopotamia Persia and Central Asia from the Muslim Conquest to the Time of Timur. Cambridge, 1905.

About the primary author: Ramil M. Valeev - Doctor of Sciences (History), Professor of the Department of Altaic and Chinese studies, Institute of International Relations, History and Oriental Studies, Kazan (Volga Region) Federal University (e-mail: valeev200655@mail.ru); 